\title{
Preface: Towards a full greenhouse gas balance of the biosphere
}

\author{
L. Merbold ${ }^{1}$, G. Wohlfahrt ${ }^{2,3}$, K. Butterbach-Bahl ${ }^{4,5}$, K. Pilegaard ${ }^{6}$, T. DelSontro ${ }^{7,8}$, P. Stoy ${ }^{9}$, and D. Zona ${ }^{10,11}$ \\ ${ }^{1}$ Institute of Agricultural Sciences, ETH Zurich, 8092 Zurich, Switzerland \\ ${ }^{2}$ Institute of Ecology, University of Innsbruck, 6020 Innsbruck, Austria \\ ${ }^{3}$ European Academy of Bolzano, 39100 Bolzano, Italy \\ ${ }^{4}$ Karlsruhe Institute of Technology, Institute for Meteorology and Climate Research, Atmospheric Environmental Research \\ (IMK-IFU), 82467 Garmisch-Partenkirchen, Germany \\ ${ }^{5}$ International Livestock Research Institute, Old Naivasha Road, Nairobi 00100, Kenya \\ ${ }^{6}$ Center for Ecosystems and Sustainability, Department of Chemical and Biochemical Engineering, Technical University of \\ Denmark, 4000 Roskilde, Denmark \\ ${ }^{7}$ Institute of Biogeochemistry and Pollutant Dynamics, ETH Zurich, 8092 Zurich, Switzerland \\ ${ }^{8}$ Department of Biological Sciences, University of Quebec at Montreal, Montreal, QC, H2J 2K9, Canada \\ ${ }^{9}$ Department of Land Resources and Environmental Sciences, Montana State University, Bozeman, MT 59717-3120, USA \\ ${ }^{10}$ Department of Animal and Plant Science, University of Sheffield, Western Bank, Sheffield, S10 2TN, UK \\ ${ }^{11}$ Department of Biology, San Diego State University, 5500 Campanile Drive, San Diego, CA 92182, USA
}

Correspondence to: G. Wohlfahrt (georg.wohlfahrt@uibk.ac.at)

Ecosystem greenhouse gas (GHG) emissions $\left(\mathrm{CO}_{2}, \mathrm{CH}_{4}\right.$, and $\mathrm{N}_{2} \mathrm{O}$ ) represent a major driver of global environmental change (IPCC, 2014). While there exists an emerging understanding on the net exchange of $\mathrm{CO}_{2}$ across terrestrial and aquatic ecosystems due in part to the existence of large measurement and modeling networks (Baldocchi et al., 2001; Friend et al., 2007; Raymond et al., 2013; Tranvik et al., 2009), similar information on the biosphere-atmosphere exchange of non- $\mathrm{CO}_{2}$ greenhouse gases (i.e., $\mathrm{CH}_{4}$ and $\mathrm{N}_{2} \mathrm{O}$ ) is sparsely available in comparison. To date, a strong focus has been given to so-called high-emission ecosystems, such as wetlands, rivers and lakes, rice cultivations and ruminants for $\mathrm{CH}_{4}$ (Nisbet et al., 2014) and agricultural ecosystems for $\mathrm{N}_{2} \mathrm{O}$ emissions (Butterbach-Bahl et al., 2013; Sutton et al., 2007). Even though $\mathrm{CO}_{2}, \mathrm{CH}_{4}$, and $\mathrm{N}_{2} \mathrm{O}$ emissions have been increasing during the last century, a combined quantification of the exchange of these three major greenhouse gases from a wide range of terrestrial and aquatic ecosystems is still missing. Therefore, approaches to develop full greenhouse gas monitoring networks, as currently undertaken in larger environmental research infrastructures such as ICOS (Integrated Carbon Observation System) and NEON (National Ecological Observation Network), are highly valuable.

The recently finished COST Action ES0804 - Advancing the integrated monitoring of trace gas exchange Between Biosphere and Atmosphere (ABBA) - evaluated the current state of greenhouse gas flux monitoring stations in Europe as a first step and initiated multi-flux monitoring sites in a second stage. In a third step, an initiative on scaling data collected at the site level to larger scales was undertaken. The fourth goal of the project was to train future researchers on experimental flux measurements as well as to introduce the next generation of researchers to modeling approaches. Under the auspices of Working Group 2 of ABBA, which focused on multi-flux monitoring sites, a full day session during the European Geosciences Union (EGU) General Assembly was organized in both 2012 and 2013 to exchange knowledge and discuss advantages and limitations of ecosystemscale $\mathrm{CH}_{4}$ and $\mathrm{N}_{2} \mathrm{O}$ exchange observations. The session further focused on bridging the terrestrial and the aquatic research communities, who often act independently despite having similar research questions. In a synthesis sub-session, researchers discussed how to bring the knowledge gained at plot or ecosystem level to larger regional and continental scales via modeling approaches. Both sessions resulted in this Special Issue with which we aim to answer the following three questions: 
1. What is the magnitude of $\mathrm{N}_{2} \mathrm{O}$ and $\mathrm{CH}_{4}$ emissions in different ecosystems and what are the respective driving forces?

2. What are the difficulties in measuring and modeling their exchange rates and how do these rates relate to ecosystem $\mathrm{C}$ and $\mathrm{N}$ turnover?

3. How do non- $\mathrm{CO}_{2}$ greenhouse gases $\left(\mathrm{CH}_{4}\right.$ and $\left.\mathrm{N}_{2} \mathrm{O}\right)$ contribute to the total global warming potential of terrestrial and aquatic ecosystems?

The manuscripts included in this Special Issue investigate GHG emissions from a variety of aquatic and terrestrial ecosystems, ranging from freshwater rivers (Maeck et al., 2014) and lakes (Sturm et al., 2014) to grasslands (Hörtnagl and Wohlfahrt, 2014, Imer et al., 2013, Merbold et al., 2013), crops (Savage et al., 2014), forest ecosystems (Peichl et al., 2014; Wang et al., 2013), and peatlands (Tupek et al., 2015). The climate zones covered ranged from the boreal region (Hanis et al., 2013) via the temperate zone (Imer et al., 2013) to the tropics (Jamali et al., 2013; Werner et al., 2014). Multi-site studies, which comprised approximately half of the Special Issue contributions, compared different ecosystem types (Luo et al., 2013), investigated effects of gradients in elevation (Teh et al., 2014) and soil moisture (Tupek et al., 2015), ecosystem management (Imer et al., 2013, SchrierUijl et al., 2014), and forest age (Peichl et al., 2014). Hiller et al. (2014) scaled up anthropogenic and natural $\mathrm{CH}_{4}$ emissions to the country scale, and Tian et al. (2013) and Kim and Kirschbaum (2014) conducted global analyses. Around one third of the papers covered all three major greenhouse gases $\left(\mathrm{CO}_{2}, \mathrm{CH}_{4}\right.$ and $\left.\mathrm{N}_{2} \mathrm{O}\right)$, while most studies discussed at least two of them. The first major result of these papers is that the contribution of the $\mathrm{CH}_{4}$ and $\mathrm{N}_{2} \mathrm{O}$ exchange to the total GHG budget varied considerably, from small and intermediate (Merbold et al., 2013; Peichl et al., 2014) to up to $50 \%$ (Hörtnagl and Wohlfahrt, 2014). Thus, this Special Issue drives the existing knowledge base substantially towards a more comprehensive quantification of the total ecosystem greenhouse gas balance.

A mix of experimental methods was employed amongst the contributed studies. Traditionally, chambers were the method of choice for flux measurements, and were also employed in many of the contributing manuscripts (Imer et al., 2013; Podgrajsek et al., 2014). Chamber measurements, however, are now increasingly complemented with or replaced by eddy-covariance flux measurements (Podgrajsek et al., 2014; Wang et al., 2013), which are facilitated by the technical advance of fast-response gas analyzers (Peltola et al., 2014; Savage et al., 2014). Challenges in measuring reliable fluxes with the various methods were discussed, in particular regarding $\mathrm{CH}_{4}$ and $\mathrm{N}_{2} \mathrm{O}$ and the spatiotemporal heterogeneity of their exchange (Maeck et al., 2014; Podgrajsek et al., 2014; Savage et al., 2014; Werner et al., 2014). A great example of this is the role of $\mathrm{CH}_{4}$ ebullition from aquatic ecosystems, which are not only difficult to accurately quantify but also tend to dominate total emissions from aquatic systems where ebullition is common (Maeck et al., 2014; Sturm et al., 2014). This highlights the second major insight from this Special Issue, the importance of hot spots and hot moments that need to be considered when designing chamber flux sampling schemes and interpreting eddy-covariance flux data (Hörtnagl and Wohlfahrt, 2014; Imer et al., 2013; Savage et al., 2014).

Finally, as the third major result the papers in this Special Issue show that $\mathrm{N}_{2} \mathrm{O}$ fluxes tend to be explained poorly by micrometeorological and hydrological variables (Luo et al., 2013; Merbold et al., 2013), suggesting that substrate availability and/or microbial community dynamics may play important roles. In contrast, abiotic drivers, and in particular soil water content, exhibited considerably more skill in predicting the sign and magnitude of $\mathrm{CH}_{4}$ exchange (Tupek et al., 2015; Wang et al., 2013).

Thereby, this Special Issue emphasizes the necessity of concerted collaboration between different disciplines and the research communities for developing more comprehensive approaches. Ultimately, continued exchanges similar to those demonstrated herein will lead to a better understanding of the feedbacks that biosphere-atmosphere greenhouse gas exchange exerts on climate.

Acknowledgements. We gratefully acknowledge the financial support of the European Cooperation in Science and Technology (COST) for the COST Action ES0804 - Advancing the integrated monitoring of trace gas exchange Between Biosphere and Atmosphere (ABBA).

\section{References}

Baldocchi, D., Falge, E., Gu, L. H., Olson, R., Hollinger, D., Running, S., Anthoni, P., Bernhofer, C., Davis, K., Evans, R., Fuentes, J., Goldstein, A., Katul, G., Law, B., Lee, X. H., Malhi, Y., Meyers, T., Munger, W., Oechel, W., U, K. T. P., Pilegaard, K., and Schmid, H. P., Valentini, R., Verma, S., Vesala, T., Wilson, K., and Wofsy, S.: FLUXNET: A new tool to study the temporal and spatial variability of ecosystem-scale carbon dioxide, water vapor, and energy flux densities, B. Am. Meteorol. Soc., 82, 2415-2434, 2001.

Butterbach-Bahl, K., Baggs, E. M., Dannenmann, M., Kiese, R., and Zechmeister-Boltenstern, S.: Nitrous oxide emissions from soils: how well do we understand the processes and their controls?, Philos. Trans. Roy. Soc. B, 368, 20130122, doi:10.1098/rstb.2013.0122, 2013.

Friend, A. D., Arneth, A., Kiang, N. Y., Lomas, M., Ogee, J., Roedenbeckk, C., Running, S. W., Santaren, J.-D., Sitch, S., Viovy, N., Woodward, F. I., and Zaehle, S.: FLUXNET and modelling the global carbon cycle, Glob. Change Biol., 13, 610-633, 2007.

Hanis, K. L., Tenuta, M., Amiro, B. D., and Papakyriakou, T. N.: Seasonal dynamics of methane emissions from a subarctic fen 
in the Hudson Bay Lowlands, Biogeosciences, 10, 4465-4479, doi:10.5194/bg-10-4465-2013, 2013.

Hiller, R. V., Bretscher, D., DelSontro, T., Diem, T., Eugster, W., Henneberger, R., Hobi, S., Hodson, E., Imer, D., Kreuzer, M., Künzle, T., Merbold, L., Niklaus, P. A., Rihm, B., Schellenberger, A., Schroth, M. H., Schubert, C. J., Siegrist, H., Stieger, J., Buchmann, N., and Brunner, D.: Anthropogenic and natural methane fluxes in Switzerland synthesized within a spatially explicit inventory, Biogeosciences, 11, 1941-1959, doi:10.5194/bg-11-1941-2014, 2014.

Hörtnagl, L. and Wohlfahrt, G.: Methane and nitrous oxide exchange over a managed hay meadow, Biogeosciences, 11, 72197236, doi:10.5194/bg-11-7219-2014, 2014.

Imer, D., Merbold, L., Eugster, W., and Buchmann, N.: Temporal and spatial variations of soil $\mathrm{CO}_{2}, \mathrm{CH}_{4}$ and $\mathrm{N}_{2} \mathrm{O}$ fluxes at three differently managed grasslands, Biogeosciences, 10, 5931-5945, doi:10.5194/bg-10-5931-2013, 2013.

IPCC: Summary for Policymakers, in: Climate Change 2014: Impacts, Adaptation, and Vulnerability, Part A: Global and Sectoral Aspects. Contribution of Working Group II to the Fifth Assessment Report of the Intergovernmental Panel on Climate Change, edited by: Field, C. B., Barros, V. R., Dokken, D. J., Mach, K. J., Mastrandrea, M. D., Bilir, T. E., Chatterjee, M., Ebi, K. L., Estrada, Y. O., Genova, R. C., Girma, B., Kissel, E. S., Levy, A. N., Maccracken, S., Mastrandrea, P. R., White, L. L., Cambridge, United Kingdom, and New York, NY, USA, Cambridge University Press, 1-32, 2014

Jamali, H., Livesley, S. J., Hutley, L. B., Fest, B., and Arndt, S. K.: The relationships between termite mound $\mathrm{CH}_{4} / \mathrm{CO}_{2}$ emissions and internal concentration ratios are species specific, Biogeosciences, 10, 2229-2240, doi:10.5194/bg-10-2229-2013, 2013.

Kim, D.-G. and Kirschbaum, M. U. F.: The effect of land-use change on the net exchange rates of greenhouse gases: a metaanalytical approach, Biogeosciences Discuss., 11, 1053-1095, doi:10.5194/bgd-11-1053-2014, 2014.

Luo, G. J., Kiese, R., Wolf, B., and Butterbach-Bahl, K.: Effects of soil temperature and moisture on methane uptake and nitrous oxide emissions across three different ecosystem types, Biogeosciences, 10, 3205-3219, doi:10.5194/bg-10-3205-2013, 2013.

Maeck, A., Hofmann, H., and Lorke, A.: Pumping methane out of aquatic sediments - ebullition forcing mechanisms in an impounded river, Biogeosciences, 11, 2925-2938, doi:10.5194/bg11-2925-2014, 2014.

Merbold, L., Steinlin, C., and Hagedorn, F.: Winter greenhouse gas fluxes $\left(\mathrm{CO}_{2}, \mathrm{CH}_{4}\right.$ and $\left.\mathrm{N}_{2} \mathrm{O}\right)$ from a subalpine grassland, Biogeosciences, 10, 3185-3203, doi:10.5194/bg-10-3185-2013, 2013.

Nisbet, E. G., Dlugokencky, E. J., and Bousquet, P.: Methane on the Rise-Again, Science, 343, 493-495, 2014.

Peichl, M., Arain, A. M., Moore, T. R., Brodeur, J. J., Khomik, M., Ullah, S., Restrepo-Coupé, N., McLaren, J., and Pejam, M. R.: Carbon and greenhouse gas balances in an age sequence of temperate pine plantations, Biogeosciences, 11, 5399-5410, doi:10.5194/bg-11-5399-2014, 2014.

Peltola, O., Hensen, A., Helfter, C., Belelli Marchesini, L., Bosveld, F. C., van den Bulk, W. C. M., Elbers, J. A., Haapanala, S., Holst, J., Laurila, T., Lindroth, A., Nemitz, E., Röckmann, T., Vermeulen, A. T., and Mammarella, I.: Evaluating the performance of commonly used gas analysers for methane eddy covariance flux measurements: the InGOS inter-comparison field experiment, Biogeosciences, 11, 3163-3186, doi:10.5194/bg-113163-2014, 2014.

Podgrajsek, E., Sahlée, E., Bastviken, D., Holst, J., Lindroth, A., Tranvik, L., and Rutgersson, A.: Comparison of floating chamber and eddy covariance measurements of lake greenhouse gas fluxes, Biogeosciences, 11, 4225-4233, doi:10.5194/bg-114225-2014, 2014.

Raymond, P. A., Hartmann, J., Lauerwald, R. et al.: Global carbon dioxide emissions from inland waters, Nature, 503, 355-359, 2013.

Savage, K., Phillips, R., and Davidson, E.: High temporal frequency measurements of greenhouse gas emissions from soils, Biogeosciences, 11, 2709-2720, doi:10.5194/bg-11-2709-2014, 2014.

Schrier-Uijl, A. P., Kroon, P. S., Hendriks, D. M. D., Hensen, A., Van Huissteden, J., Berendse, F., and Veenendaal, E. M.: Agricultural peatlands: towards a greenhouse gas sink - a synthesis of a Dutch landscape study, Biogeosciences, 11, 4559-4576, doi:10.5194/bg-11-4559-2014, 2014.

Sturm, K., Yuan, Z., Gibbes, B., Werner, U., and Grinham, A.: Methane and nitrous oxide sources and emissions in a subtropical freshwater reservoir, South East Queensland, Australia, Biogeosciences, 11, 5245-5258, doi:10.5194/bg-11-5245-2014, 2014.

Sutton, M. A., Nemitz, E., Erisman, J. W., Beier, C., Bahl, K. B., Cellier, P., de Vries, W., Cotrufo, F., Skiba, U., Di Marco, C., Jones, S., Laville, P., Soussana, J. F., Loubet, B., Twigg, M., Famulari, D., Whitehead, J., Gallagher, M. W., Neftel, A., Flechard, C. R., Herrmann, B., Calanca, P. L., Schjoerring, J. K., Daemmgen, U., Horvath, L., Tang, Y. S., Emmett, B. A., Tietema, A., Penuelas, J., Kesik, M., Brueggemann, N., Pilegaard, K., Vesala, T., Campbell, C. L., Olesen, J. E., Dragosits, U., Theobald, M. R., Levy, P., Mobbs, D. C., Milne, R., Viovy, N., Vuichard, N., Smith, J. U., Smith, P., Bergamaschi, P., Fowler, D., and Reis, S.: Challenges in quantifying biosphere-atmosphere exchange of nitrogen species, Environ. Pollut., 150, 125-139, 2007.

Teh, Y. A., Diem, T., Jones, S., Huaraca Quispe, L. P., Baggs, E., Morley, N., Richards, M., Smith, P., and Meir, P.: Methane and nitrous oxide fluxes across an elevation gradient in the tropical Peruvian Andes, Biogeosciences, 11, 2325-2339, doi:10.5194/bg-11-2325-2014, 2014.

Tian, H., Chen, G., Lu, C., Xu, X., Ren, W., Banger, K., Zhang, B., Tao, B., Pan, S., Liu, M., and Zhang, C.: Global landatmosphere exchange of methane and nitrous oxide: magnitude and spatiotemporal patterns, Biogeosciences Discuss., 10, 19811-19865, doi:10.5194/bgd-10-19811-2013, 2013.

Tranvik, L. J., Downing, J. A., Cotner, J. B., Loiselle, S. A., Striegl, R. G., Ballatore, T. J., Dillon, P., Finlay, K., Fortino, K., Knoll, L. B., Kortelainen, P. L., Kutser, T., Larsen, S., Laurion, I., Leech, D. M., McCallister, S. L., McKnight, D. M., Melack, J. M., Overholt, E., Porter, J. A., Prairie, Y., Renwick, W. H., Roland, F., Sherman, B. S., Schindler, D. W., Sobek, S., Tremblay, A., Vanni, M. J., Verschoor, A. M., von Wachenfeldt, E., and Weyhenmeyer, G. A.: Lakes and reservoirs as regulators of carbon cycling and climate, Limnol. Oceanogr., 54, 2298-2314, 2009.

Tupek, B., Minkkinen, K., Pumpanen, J., Vesala, T., and Nikinmaa, E.: $\mathrm{CH}_{4}$ and $\mathrm{N}_{2} \mathrm{O}$ dynamics in the boreal forest-mire ecotone, Biogeosciences, 12, 281-297, doi:10.5194/bg-12-2812015, 2015. 
Wang, J. M., Murphy, J. G., Geddes, J. A., Winsborough, C. L., Basiliko, N., and Thomas, S. C.: Methane fluxes measured by eddy covariance and static chamber techniques at a temperate forest in central Ontario, Canada, Biogeosciences, 10, 43714382, doi:10.5194/bg-10-4371-2013, 2013.
Werner, C., Reiser, K., Dannenmann, M., Hutley, L. B., Jacobeit, J., and Butterbach-Bahl, K.: $\mathrm{N}_{2} \mathrm{O}, \mathrm{NO}, \mathrm{N}_{2}$ and $\mathrm{CO}_{2}$ emissions from tropical savanna and grassland of northern Australia: an incubation experiment with intact soil cores, Biogeosciences, 11, 6047-6065, doi:10.5194/bg-11-6047-2014, 2014. 